特集・第 4 回環境用水の污濁と光の浄化シンポジウムよりり

\title{
ウォーターレタスにょる栄養塩除去と 大規模生育実験
}

青井 透* -大月 伸浩* - 臼田 寛**

\section{1.はじめに}

利根川水系は首都圈約 2,600 万人の飲料水源であ るが，利根川水系の上中流部に位置するほとんどの 下水処理施設は，湖沼法の適用を受けて抢らず，そ のため特に窒素, リンの除去を行っていないため, 下水道の普及に伴い河川や湖沼における富栄養化 （霞ヶ浦や渡良瀬貯水池などに代表される）は進行 しつつあり，飲料水源としての利用に制限を加えて いる（例えば平成 6 年夏の大渇水のとき, 渡良瀬貯 水池の水はアオコの繁殖により上水源として利用で きなかった)。この富栄養化防止の方策は多数ある が,この中で水生植物を利用した栄養塩除去技術は, 水面と太陽エネルギーを利用するため「エコロジー かつエコノミー」な技術である。

水生植物は，ホテイアオイのように水面に浮遊す る浮漂性植物と, ヨシのように根を底土にはる抽水 性植物等に分けられるが，浮漂性植物は自由水面を そのまま利用できるために, 成長植物体の回収が可 能であれば, 水質浄化への適用としては抽水性植物 の利用に比べてよりエコノミーであり，柔軟な対応 が可能である．浮漂性植物の代表とされるホテイア オイについては, 既に多くの研究がなされているが, いまだに実用化されていないのは，過大になる成長 植物体の水域からの回収が困難であることが, 大き な要因と考えられる。

著者らは, 浮漂性植物による水質浄化技術に, ホ テイアオイに代わる植物としてウォーターレタス

（写真 1 に屋外連続実験時の外観を示した）を取り 上げ研究を行ってきた ${ }^{1 \sim 6)}$.ウォーターレタスは熱帯 アフリカ原産の多年性水生植物で, 繁殖茎を分離す

* 群馬工業高等専門学校環境都市工学科 Toru AOI,

Nobuhiro OTSUKI

**東洋建設(侏) Hiroshi USUDA

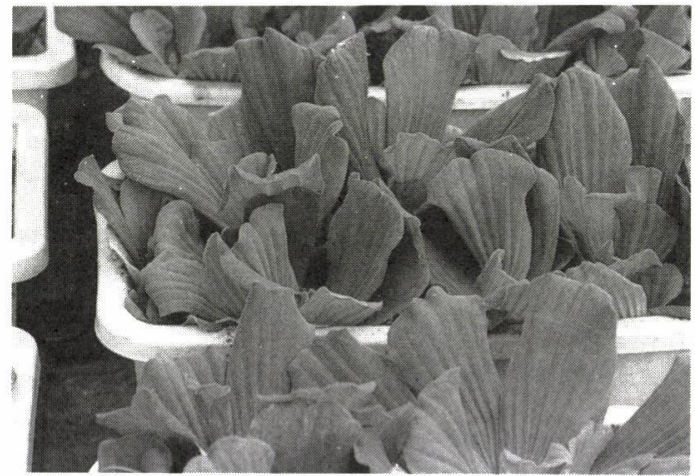

写真 1 ウォーターレタスの外観（屋外連続実験）

ることで増殖する。この植物はホテイアオイのよう に成長して枝が絡んで一体化することがなく，単株 で浮遊するという特徵があり, 単株当たりの湿重量 も最大 $500 \mathrm{~g}$ 程度と過大化しないために, 水面からの 回収が行いやすい（ラジコンボートでも回収可能） のが利点である.また,このウオーターレタスは $\mathrm{NH}_{4}-\mathrm{N}$ と $\mathrm{NO}_{\mathrm{X}}-\mathrm{N}$ が同時に存在する場合, $\mathrm{NH}_{4}-\mathrm{N}$ を優先的に除去することや，梅雨期における低日照 時, 夏季に扔ける高温時のいずれの場合でもホテイ アオイに比べて高い増殖速度を示すことが分かって いる. 古川らも, 生活排水で污濁した水路での生育 実験で, ウォーターレタスのほうがホテイアオイよ り生育速度が速かったと報告している77.

本論文では, ウォーターレタスの屋内回分実験に よる窒素・リン物質収支, 屋外連続実験による栄養 塩の除去速度, 及び実際のため池を用いた大規模生 育実験を行い，閉鎖性水域における実用化について 検討を行ったので報告する。

\section{2. 実験内容および方法}

\section{1 屋内回分実験}




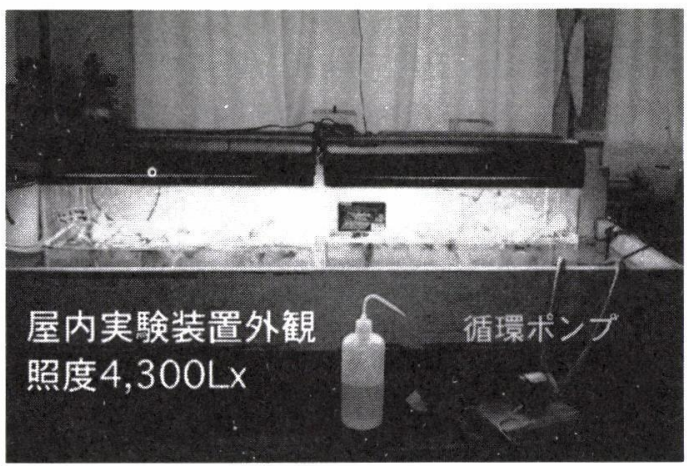

写真 2 屋内回分実験装置外観

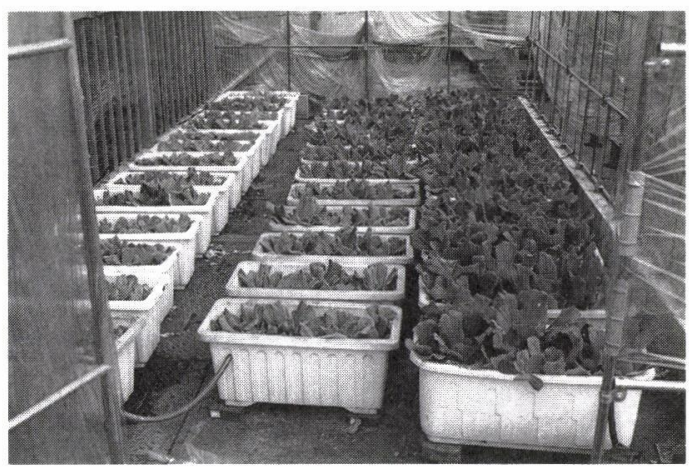

写真 3 屋外連続実験装置外観
$60 \mathrm{~cm}$ 熱带魚用ガラス水槽を 3 基，屋内の恒温槽に 設置し, 一定温度・一定照度の条件で, 基質とする 窒素の成分を変化させ $\left(\mathrm{NH}_{4}-\mathrm{N}, \mathrm{NO}_{3}-\mathrm{N}, \mathrm{NH}_{4}-\mathrm{N}+\right.$ $\mathrm{NO}_{3}-\mathrm{N}$ ：基質として $\mathrm{NH}_{4} \mathrm{Cl}, \mathrm{KNO}_{3}, \mathrm{~K}_{2} \mathrm{HPO}_{4}$ を使 用し微量栄養源として活性污泥処理水を添加), ウォ ーターレタスの回分生育実験を行った。毎白の植物 生育量を計測するとともに，水質を測定した。水中 より除去された $\mathrm{N}, \mathrm{P}$ 量を水質データから計算し, 実験終了時に植物体に含まれる $\mathrm{N}, \mathrm{P}$ 量を分析して 物質収支を求めた。水質分析には $\mathrm{NH}_{4}-\mathrm{N}$ (インドフ エノール比色法), $\mathrm{NO}_{\mathrm{x}}-\mathrm{N}$ ( 2 波長紫外部吸光度法), $\mathrm{PO}_{4}-\mathrm{P}$ (モリブデン青・アスコルビン酸法) により 行った. 実験装置の外観を写真 2 に示す.

\section{2 屋外連続実験}

当高専合併処理浄化槽（1,200人槽 - 接触曝気法） の消毒前処理水を原水とし, 定量ポンプで各容量 12 $\ell$ の直列36連のプランターに供給した。この実験装 置全体がハウス内に設置されているので雨による影 響は受けない。ウォーターレタスは旺盛な繁殖を示 すので，時々余剰の植物体を間引いて管理した。写 真 3 に屋外連続実験装置の外観を示した。水質分析 方法は2.1と同様である。

\section{3 ため池での大規模生育実験}

本校には長さ約 $130 \mathrm{~m}$, 幅約 $60 \mathrm{~m}$, 水面積 $7850 \mathrm{~m}^{2}$ の 農業用ため池があるので，このため池で大規模生育 実験を行った。このため池 (HRT 2-4 日) は，高 専周辺の市街化が進んだにもかかわらず市街化調整 区域に位置するため, 下水道が未整備で生活雑排水 の混入が著しく, 池の底には降雨時に水路の底から 巻上げられ流入した有機污濁物がへドロ状に沈積し 嫌気的分解をしている. 池水の浄化をはかるため,
ため池水面の一部をフロートフェンス（発砲スチロ 一ル使用, 面積 $1500 \mathrm{~m}^{2}$ ) で仕切り, 別な場所で育成 したウォーターレタスを移送して成長状況を観察し た。また湖岸に $50 \mathrm{~mm}$ 塩ビ管を接続し底部に金網を張 った浮揚性のフレーム（幅 $1 \mathrm{~m} \times$ 長さ $1.5 \mathrm{~m} \& 2 \mathrm{~m}$ ) を複数製作し，そのなかでウォーターレタスとホテ イアオイを一定株数育成して増殖速度の観察を行っ た。

\section{3.結果および考察}

\section{1 屋内回分実験における栄養塩の物質収支}

物質収支を求める屋内回分実験の実験条件一覧を 表 1 に示す. 3 系列の実験を同時にスタートしたが, 窒素の基質としては窒素濃度は同一とし, $\mathrm{NH}_{4}-\mathrm{N}$, $\mathrm{NH}_{4}-\mathrm{N}+\mathrm{NO}_{3}-\mathrm{N}, \mathrm{NO}_{3}^{*}-\mathrm{N}$ の 3 種類を使用した. 開 始時の窒素濃度は $40 \mathrm{mg} / \ell$, リン濃度は $5 \mathrm{mg} / \ell$ とし た。照明には 2 灯式の植物生育用蛍光灯を 2 基使用 し終日照明とした。水温は恒温槽で $20^{\circ} \mathrm{Cに}$ に保った。 図一 1 には, 屋内回分実験での植物湿重量の経日変 化を示した。最も速く成長したのは $\mathrm{NH}_{4}-\mathrm{N}+\mathrm{NO}_{3}-$ $\mathrm{N}$ を窒素源に用いたもの, 次に $\mathrm{NH}_{4}-\mathrm{N}$ を用いたも ので, $\mathrm{NO}_{3}-\mathrm{N}$ を用いたものの成長が最も遅かった。

表 1 物質収支を求める屋内回分実験条件一覧

\begin{tabular}{l|c|r|r|r}
\hline \multicolumn{1}{c|}{ 基 質 } & 濃度 & RUN 1 & RUN 2 & RUN 3 \\
\hline $\mathrm{NH}_{4}-\mathrm{N}$ & $\mathrm{mg} / \ell$ & 40 & 0 & 20 \\
$\mathrm{NO}_{3}-\mathrm{N}$ & $\mathrm{mg} / \boldsymbol{\ell}$ & 0 & 40 & 20 \\
$\mathrm{NH}-\mathrm{N}+\mathrm{N}_{\mathrm{x}}-\mathrm{N}$ & $\mathrm{mg} / \boldsymbol{\ell}$ & 40 & 40 & 40 \\
$\mathrm{PO}_{4}-\mathrm{P}$ & $\mathrm{mg} / \boldsymbol{\ell}$ & 5 & 5 & 5 \\
\hline
\end{tabular}

注記: $\mathrm{T}_{\mathrm{w}}=20^{\circ} \mathrm{C}$, 照度 $4,300 \mathrm{Lx}$ 微量栄責素として活性污泥処理水を各 $500 \mathrm{~m} \ell$ 添加 


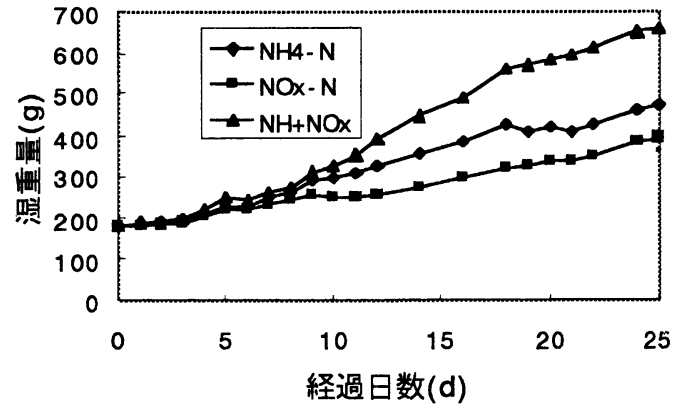

図一 1 屋内回分実験での植物量の経日変化
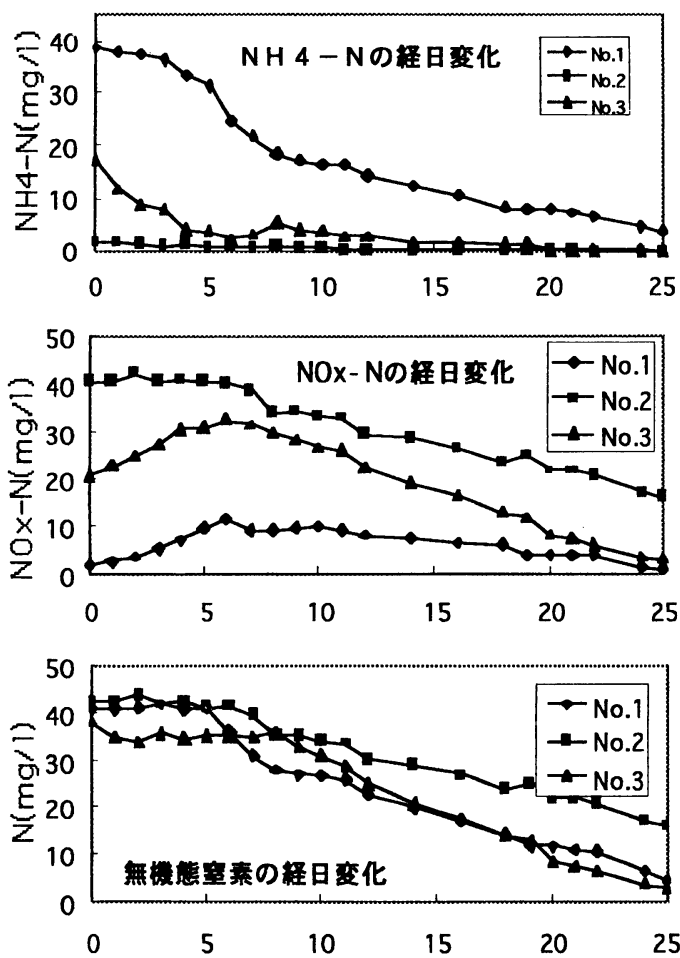

経過日数(d)

図一2 屋内回分実験での各態窒素の経日変化
図一 2 には同回分実験での各水槽内の各態窒素の濃 度変化を示した。 $\mathrm{NH}_{4}-\mathrm{N}$ を用いた実験では $\mathrm{NH}_{4}-$ $\mathrm{N}$ の減少と $\mathrm{NO}_{3}-\mathrm{N}$ の増加が観察され, 植物の根に 付着した微生物による硝化が起こっているものと思 われる. 実験終了後, 生育した植物を乾燥させ，含 まれている窒素・リン・カリの分析を行った。この 数值と実験終了時の植物重量から除去された $\mathrm{N}, \mathrm{P}$ 量が計算できる。また水系からの窒素・リンの除去 量も計算できるので物質収支の検討を行った．表 2 にこれらの結果を示した.リンについては水系から 除去された量と植物が回収した量はほぼ等量である が，窒素については水系からの減小量に対して植物 に固定された量は 43-60\%であり,植物に固定された 量とほぼ同量が脱窒素により除去されているものと 想定される.ウォーターレタスが繁殖したときに根 周辺のD O は大幅に低下することも, 脱窒素が起こ っていることを示唆している.

\section{2 屋外連続実験による栄養塩除去特性}

今回行った屋外連続実験の概要を表 3 に示す．表 3 には, 概略の窒素除去速度も示した. 図一 3 に示 した実験装置では，右手前の水槽に流入した原水が 36 本のプランター（水深は約 $20 \mathrm{~cm} ）$ を経由して流出 するが，その間でN，Pの除去が行われるので，ウ オーターレタスの外観・色は入口と出口では大幅に 変化していることが分かる。図一 3 には，屋外連続 実験各 RUN でのN, P濃度の経日変化を示した.実 験は夏季に行ったので, 日照・水温ともに充分な条 件であり最大除去速度で除去が行われる環境であ る.図一3の RUN 3 では, 滞留時間が70時間と長い ためにほほ半分の時間 (1.5日) でほぼ全量の窒素が 除去されている。このときの植物量は概ね $15 \mathrm{~kg}$ $\mathrm{Wet} / \mathrm{m}^{2}$ であり，ほぼ飽和の状態であった。次の RUN 4 は滞留時間を33時間に短縮して行ったが, この実験を行う 4 日前に植物を $50 \%$ 程度間引いたた めに見かけ上の窒素除去速度は 5 $\mathrm{mg} / \ell /$ 日と低下しているが，この 後行った RUN 5 では再び植物量 が飽和状態に回復したために, 窒 素除去速度は $10 \mathrm{mg} / \ell /$ 日となって いる.このように $\mathrm{N}, \mathrm{P}$ ともにほ ぼ直線的に除去されており，その 除去速度は $\mathrm{N}$ (as $\mathrm{NO}_{3}-\mathrm{N}$ ) 10mg/ $\ell /$ 日, $\mathrm{P} 2 \mathrm{mg} / \ell /$ 日程度であり， 植物による処理としては非常に高 
表 3 屋外連続実験概要

\begin{tabular}{c|l|l|c}
\hline 略 号 & \multicolumn{1}{|c|}{ 実験日 } & \multicolumn{1}{|c|}{ 植物量 } & 窒素 $\left(\mathrm{NO}_{\mathrm{x}}-\mathrm{N}\right)$ 除去速度 \\
\hline RUN 1 & $1996.6 / 4$ & 植物がプランター内飽和状態 & \\
RUN 2 & $1996.6 / 7$ & 植物がプランター内飽和状態 & $8 \mathrm{mg} / \ell / \mathrm{day}$ \\
RUN 3 & $1996.8 / 12$ & 植物がプランター内飽和状態 & $10 \mathrm{mg} / \ell / \mathrm{day}$ \\
RUN 4 & $1996.8 / 19$ & 植物を約 $1 / 2 に$ 間引たた状態 & $5 \mathrm{mg} / \ell / \mathrm{day}$ \\
RUN 5 & $1996.8 / 26$ & RUN 2 後成長し飽和に近い状態 & $10 \mathrm{mg} / \ell / \mathrm{day}$ \\
\hline
\end{tabular}
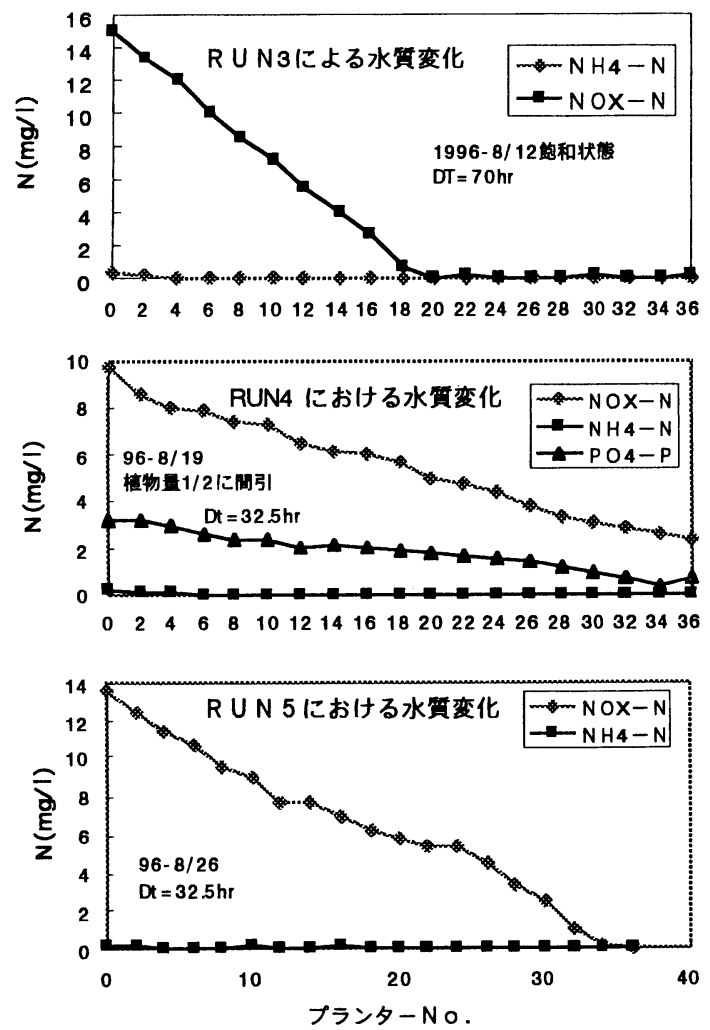

図一3 屋外連続各 RUN でのN,P濃度の経日変化

い除去速度と良好な再現性を示した。

従来植物による水質净化は，「よりまし技術(ない よりましの技術)」と言われてきたが，ウォーターレ 夕スによる水質の浄化は再現性があり, 充分に装置 化の検討が可能である．実験のほとんどは夏休み期 間となったため, 合併浄化槽の流入負荷が低く, 接 触曝気槽内で $\mathrm{NH}_{4}-\mathrm{N}$ はほぼ完全に硝化されてお り，窒素の除去速度は $\mathrm{NOx}-\mathrm{N}$ の条件しか検討でき なかったが, $\mathrm{NH}_{4}-\mathrm{N}$ の場合にはさらに除去速度は 増加すると思われる。一般的な生活排水処理施設処 理水の窒素濃度は $20-30 \mathrm{mg} / \ell$, リンは $2-3 \mathrm{mg} / \ell$ で
あるので，この連続実験のような装置で 2 日程度滞 留させれば，特に高度処理を行わなくても，処理水 中の $\mathrm{N}, \mathrm{P}$ はそのほとんどを除去することが可能で ある.

\section{3 ため池を用いた大規模生育実験}

大規模生育実験でウォーターレタスが水面をほほ 被覆した時点の外観を写真 4 に示す. 実験開始時に 約 $150 \mathrm{~m}^{2} に$ 過ぎなかったウォーターレタスは, 夏期の 高温と日照に恵まれ, 非常に高い速度で水面を被覆 してゆき, 約 2 週間でフェンス内はほとんど覆い尽 くされた（写真 4 (a) [正面］，(b) [裏面]). 写真 4 (c) は生育しているウォーターレタスの拡大写真であ る.放流して 2 週間程度しか経過していないために, 植物の単株はそれほど大きくなっておらず二次元的 に成長しており, 開水面が $2-3$ 割観察される。その 後, 局地的な夕立ちの降雨によりフェンス内ウォー ターレタスの $2 / 3$ が流出してしまったが, 残った植物 が生育を続け再び2週間後には全面を被覆した.図一 4 に大規模生育実験での水面被覆経過の一例を示 す，著者らによる過去の回分実験結果では，比増殖 速度は最高で0.11 (1/d) であったが, 比増殖速度が 0.1 というとは 10 日間で倍の重量になる計算であ り, 栽培水域を完全に被覆するまでには約一カ月を 要するはずである．しかし予想に反して約 2 週間で 水面を完全に被覆したことは，この植物が成長途中 でまず横方向に成長するため, 比増殖速度で計算し たよりも高い速度で水面を被覆したものと思われ る.

また湖岸に設置した塩ビフレーム内では, ウォー ターレタスとホテイアオイとの成長状況を比較する ために，写真 $5($ a)に示すように 8 月初めに両植物を 7 株づつ放流した。 その後観察を続けたが，14日後 ウォーターレタスはフレーム内を完全に被覆したが ホテイアオイは 9 月中旬にようやく全面を被覆し た. 全面被覆後のフレームの状況を写真 $5(\mathrm{~b})$ に示し たが, ウォーターレタスのほうが成長は旺盛であっ 


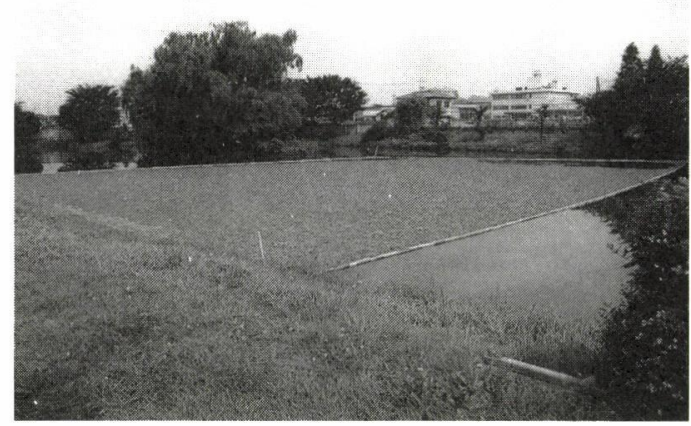

(a)

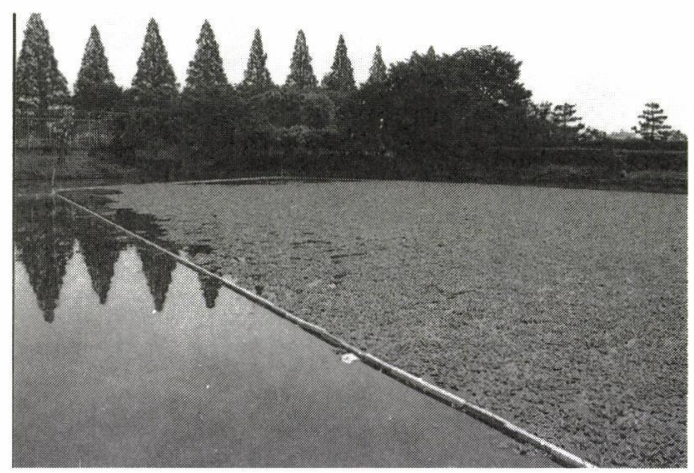

(b)

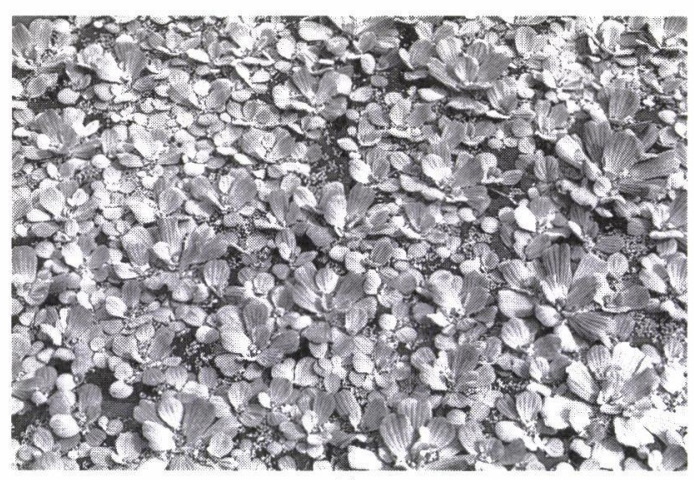

(c)

写真 4 大規模生育実験でのレタスの成長 (放流加 2 週間後(a), (b), (c))

た（中央右側がホテイアオイ，両端はウォーターレ タス).この実験の結果から, 本ため池のような環境 (本実験中の水質の一例は, 全窒素 $2.6 \mathrm{mg} / \ell(\mathrm{NOx}$ $-\mathrm{N} 1.4 \mathrm{mg} / \ell, \mathrm{NH}_{4}-\mathrm{N} 1.2 \mathrm{mg} / \ell$ ) 全リン $0.6 \mathrm{mg} / \ell$ で あった）において，ウォーターレタスはホテイアオ イに比べ，やや高い速度で成長することが確認され た.

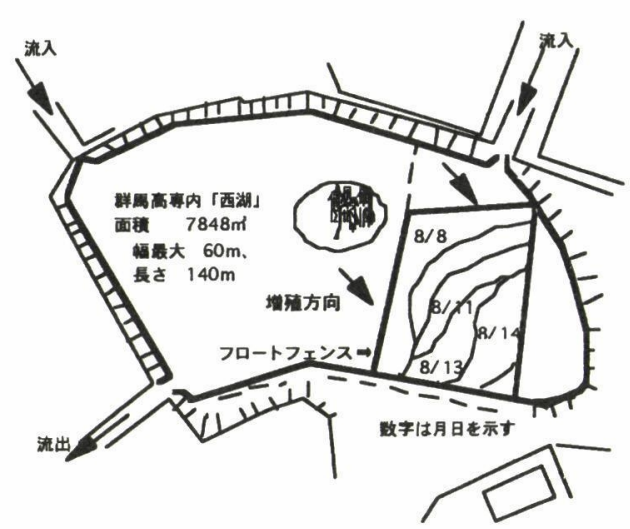

図一４大規模生育実験での水面被覆経過図

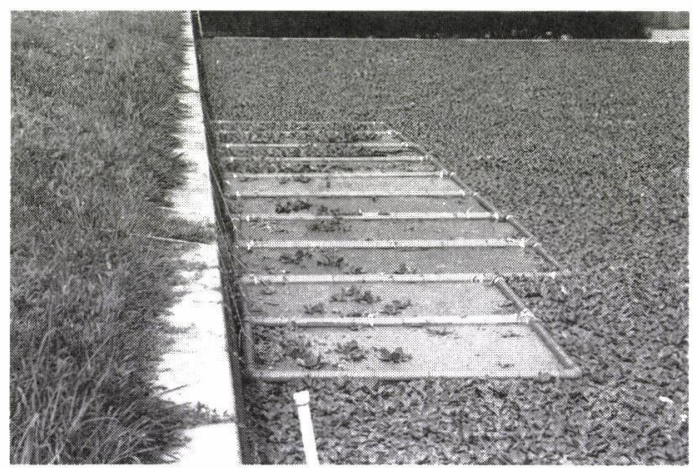

(a)

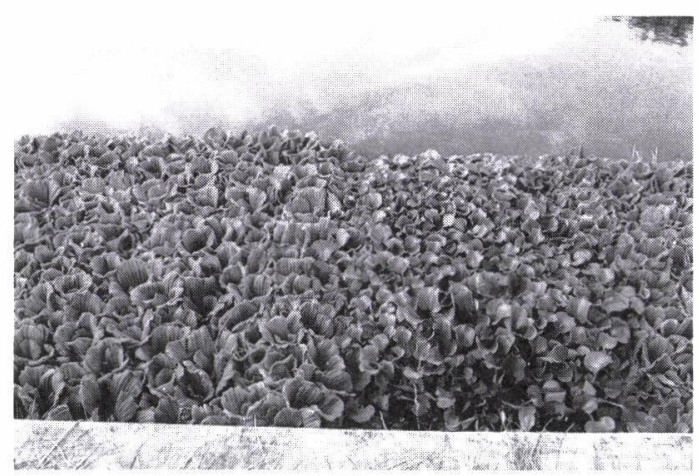

(b)

写真 5 栽培フレームでの生育実験（放流時(a)と生育後(b)）

写真 6 には最大繁殖時の外観を示す。ウォーター レタスの色は鮮やかな緑色であり, ホテイアオイの 深緑色よりも景観的には明るくて優れていると思わ れる. 大規模生育実験での植物量は最大成長時で単 位面積当たり $15 \mathrm{~kg} \mathrm{Wet} / \mathrm{m}^{2}$ 程度であり, 株当たりの 


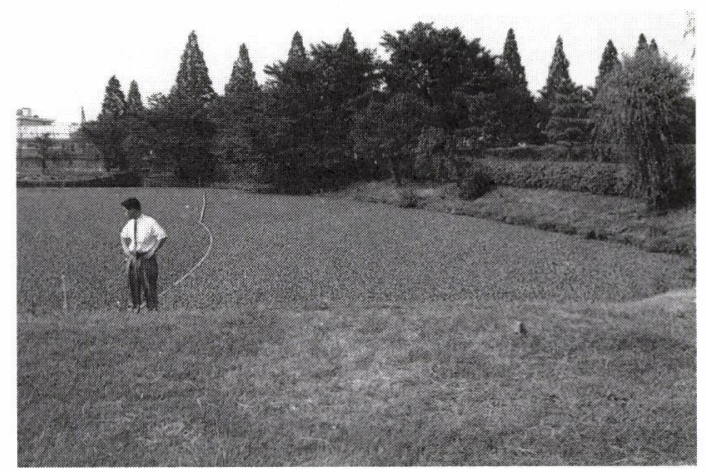

写真 6 水面被覆後のレタスの最大成長

最大湿重量は $350 \mathrm{~g}$ 程度であった.この数値は,より 高い窒素・リン濃度の浄化槽処理水を用いた連続実 験で生育したウォーターレタスの単位面積湿重量・ 個体湿重量とほほ同等であった。この植物はホテイ アオイのように枝が絡み合わず単独株で生育するた めに回収が容易であることが確認された。

\section{4.まと め}

以上に示したようなウォーターレタスの各栽培実 験より, ウォーターレタスの優れた水質浄化能力, 極めて高い増殖速度, 幅広い適用可能性が明らかと なった。特に, 農業用ため池での夏季大規模生育実 験で非常に高い水面被覆速度を示したことは, 日光 遮断によりアオコの増殖を防止できる可能性を示唆 している.この植物は熱帯原産のために冬季の低温 では生育できない（最低温度 $15^{\circ} \mathrm{C}$ ) が, 生活排水処
理水は冬季でも環境水よりも高い水温をもつてお り，太陽熱やプロセス内排熱（いわゆるソフトエネ ルギー）を有効に活用できれば, 冬季間の生育も不 可能ではない。かりに冬季間の生育が困難としても 4 月から 12 月まではこの植物の利用は可能であり, 浄化に用いられる植物の中では汎用性が高いと思わ れる。

今後は，ため池を用いて水面からの回収システム の開発と回収植物体の堆肥化について,引き続き検 討を進めて行きたい.

\section{参 考 文 献}

1) 大庭栄次, 青井 透 (1995) 水草 (ウォーターレタス)を 用いた合併処理浄化槽処理水からの $N, P$ 除去, 第32回下 水道研究発表会講演集, pp646-648

2 ) 大島秀則, 青井 透, 林 俱子 (1996) ウォーターレタス とホテイアオイ植物体の有効成分組成の検討, 第30回日本 水環境学会年会講演集, $\mathrm{p} 88$

3 ）臼田 寛, 青井 透 (1996) ウォーターレタスによる環境 水浄化の実用化の検討, 第33回土木学会環境工学研究〉ォ ーラム講演集, pp39-41

4) Aoi, T., Hayashi, T. (1996) Nutrient Removal by Water Lettuce [Pistia stratiotes], Wat. Sci. Tech. 34, No. 7-8, pp407-412

5 ) 青井 透, 臼田 寛 (1996) ウォーターレタスによる水質 の浄化と生態系の復元, 環境技術, 25, pp536-536

6) 大月伸浩, 青井 透 (1997) 水質浄化に用いたウォーター レタスの堆肥化の検討, 第31回日本水環境学会年会講演集 p428

7 ) 古川憲治, 藤田正憲, 重村浩之, 平群町役場生活環境課 (1997) 各種接触坦体と水生植物の組み合わせによる生活 排水污濁水路浄化施設の処理特性, 日本水処理生物学会 誌, 33, No. 3, pp161-170

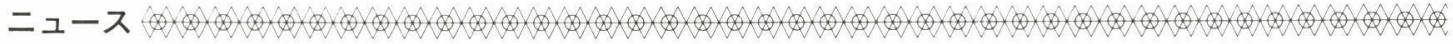

\section{ダイオキシンに関する 自主基準を発表}

一感染性廃棄物処理に関する自主基準 の改訂迫られる—

去る10月23日開催の社全国産業廃棄物連合理事会 において、かねてょり中間処理部会で検討中の「ダ イオキシン類発生抑制対策のための産業廃棄物焼却 自主基準」が正式に決定し、(1)燃焼を良くし、未燃 成分を少なくする(2)煤塵量を低減する(3)生成温度域 の滞留時間を短縮するの三点について具体的な対策
を定め、焼却におけろ燃焼管理を適正におこなうこ とによって、ダイオキシン類の発生を抑制すること にしている。

尚感染性廃棄物の処理は、現在 9 割近くが焼却処 分されているので、再三述べられているように「感 染性廃棄物処理に関する自主基準」も、当然改訂が 迫られ、10月29日開催される医療廃棄物部会運営委 員会において取り上げ、部会内に小委員会を設け具 体的な検討に入る予定である。

(社)全国産業廃棄物連合会 